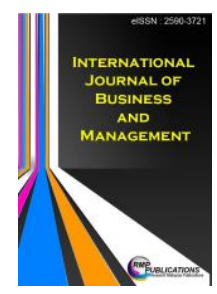

\title{
The Comparative Analysis of Profitability Visa and Mastercard Companies After Implementation of GPN as Provider of Debit Cards in Indonesia
}

\author{
Rismaladewi $^{l}$, Budi R. Kartawinata ${ }^{1}$, Imanuddin Hasbi ${ }^{l}$ and Candra Wijayangka ${ }^{l}$ \\ ${ }^{1}$ Faculty of Communication and Business, Universitas Telkom, Bandung, Indonesia.
}

\begin{abstract}
Debit card is electronic payment cards issued by banks. This card can be used instead of cash payments. In addition to making payments, debit cards are also used for instant cash withdrawals because of their function as ATM cards to withdraw cash. This study aims to compare the benefits of Visa and Mastercard companies after implementing GPN using the profitability ratio Net Profit Margin (NPM), Return on Investment (ROI) and Return on Equity (ROE). This study uses a quantitative approach using data from the company's financial statements in 2016 until 2018. The results of this study indicate that there is no significant difference in the value of NPM, ROI and ROE Visa while the ROE value of Mastercard has increased which indicates an increase in performance management in generating profits for the company
\end{abstract}

Key words: National Payment Gateway, NPM, ROI, ROE

\section{INTRODUCTION}

Debit card is electronic payment cards issued by the bank. This card can be used instead of cash payments. In addition to making payments, debit cards are also used for instant cash withdrawals because of their function as ATM cards to withdraw cash [1]. According to the official website of Bank Indonesia, debit cards are payments using cards that can be used to make payments for obligations arising from an economic activity, including spending transactions, where the cardholder's obligations are met immediately by reducing cardholder deposits directly to a bank or non-bank institution authorized to collect funds in accordance with applicable laws and regulations [2]. Debit card service companies in Indonesia are Visa and Mastercard. Visa card brands dominate the card industry with a market share of 60 percent of all cards in the world. The rest, 40 percent, divided the market share for MasterCard, Amex, Diners, JCB (Japan Card Bureu), EuroCard and others according to the compass until 2000 [3].

In Indonesia itself, the phenomenon of using debit cards is quite unique. The economic crisis that began in July 1997 had an impact on termination of employment, including professionals. As a result the ability to buy low power is included in this case the payment of credit card bills from charholders.
The broader impact of the Asian crisis is the refusal of service transactions including visas outside Asia. Especially if the Bank Iussing Card is domestic banking [3].

Based on the Payment System Statistics data released by Bank Indonesia, the number of ATM cards and debit outstanding in November 2014 reached 97.2 million, the cards grew by $14.43 \%$ in the year to date of 87.17 million pieces of card position at the end of 2013. as of November 2014, the volume of debit card transactions also grew by $6.77 \%$ to $\mathrm{Rp} 3,695$ billion from $\mathrm{Rp} 3,461$ trillion trillion at the end of 2013. for the transaction value Debit cards reached Rp4,026 trillion, an increase of 6.14\% from the end of 2013 worth Rp3,797 trillion [4].

From 2013 to 2017 the APMK infrastructure engine ATM machines experienced an average increase of 7600 each year and the development of EDC machines has increased by 180,000 EDC machines annually. The number of merchants from 2013 to 2017 alone has increased by an average of 88,000 annually [5].

With the increasing use of cards as a means of payment, the number of debit cards in circulation will also increase, in line with improved interoperability. This condition shows that non- 
cash transactions in Indonesia are growing very rapidly. Thus, the velocity of money is expected to be faster and encourage economic acceleration. However, so far the significant increase in the use and number of debit cards has been accompanied by fragmentation and efficiency. The banking system tends to be exclusive, not yet connected, and its interoperability has not been good [6].

This then underlies the Central Bank launching GPN or NPG (National Payment GatewayNational Payment Gateway) which aims to realize the interconnection and interoperability of payment systems in Indonesia and domestic transaction processing carried out domestically.

Meanwhile, if viewed from the use of foreign merchants such as Visa and MasterCard, where things are highlighted about the flow of funds originating from customer transactions, through GPN every transaction using the merchant will settle in the country so the government can more easily monitor the potential tax that can be obtained. Seeing the many advantages offered by the GPN policy, this has become a necessity so that the community is not burdened with too high costs due to the lack of integration between existing merchants/ ATMs [7].

\section{LITERATURE REVIEWS}

"Financial statement analysis applies analytical tools and techniques to general purpose financial statements and related data to estimates and in useful useful business decisions". Published financial statements are considered important in decision making. This statement was confirmed by Lev and Thiagarajan. Lev and Thiagarajan said that the analysis of financial statements which constitute accounting information is considered important to understand the information contained in these financial statements [8].

Analysis of the financial statements of a company basically because they want to know the level of profitability (profit) and the level of risk or level of health of a company. Profitability is the ability of a company to generate profits. Profitability analysis describes the company's fundamental performance in terms of the level of efficiency and effectiveness of the company's operations in obtaining profits. Conceptually, it can be concluded that the company's fundamental performance proxied through the dimensions of company profitability through stock price indicators and company capital structure is related to the size of the company's debt composition [9].

The analysis carried out by the author in this study is a horizontal analysis where horizontal analysis is used to compare data from financial statements. Horizontal analysis is an analysis that compares the company's financial ratios from past years with the aim to be able to see the trend of company ratios over a period of time [8]. The purpose of this analysis is to find out how much an increase and decrease in a post and sub-post then affects the value of a ratio.

Profitability ratios are also referred to as profitability ratios, which are ratios used to measure a company's ability to earn profits or profits) [10]. The profitability ratio is useful to show the company's success in making a profit. This ratio is intended to measure the efficiency of the use of company assets. Efficiency in this case is associated with sales that were successfully created. In addition profitability ratios can also be expressed as ratios used to measure management effectiveness seen from the lsbs that are generated against sales and investment [8].

1. Net Profit Margin, According to Jeol G. Siegel and Jae. $\mathrm{K}$ net profit margin is equal to net profit margin divided by net sales. This shows the stability of the unit to produce gains at a special level of sales [11]. 2. Return on Investment (ROI), in some other references this ratio is also written with return on total assets (ROA). This ratio provides a return on profit as expected. This ratio looks at the extent to which the investment that has been invested is able to provide returns as expected [12]. 3. Return on Equity (ROE), Return on Equity is a ratio used to measure the ability of own capital to generate profits from all shareholders, both ordinary shares and preferred shares [10].

\section{METHODOLOGY}

This study uses a comparative method where research is comparing independent variables for samples of more than one, or at different times. The source of the data comes from secondary data obtained from the quasi-investor fiscal report where Time series studies are conducted to compare data obtained in each period. Profitability ratio is used to find out the comparison of company profits seen from the value of NPM, ROI and ROE. Data analysis using descriptive statistic test, normality test and comparative hypothesis test using SPSS assistance.

\section{RESULT ANALYSIS AND DISCUSSIONS}

Test the hypothesis of comparative means test population parameters that is shaped comparison through sample size also shaped comparison. This also means test the ability to generalize (significance the results of research) comparison 
the state of a variable sample of two or more. Test the hypothesis of comparative divided into two, for data interval and ratio used statistics parametric and for nominal/discrete can be used statistics nonparametric. [13].

Statistics parametric used to test hypotheses comparative an average of two when the data sample shaped the interval or ratio by using t-test. Paired test sample t-test used to know whether there were differences in an average of two (two groups) in pairs or associated. Paired test sample ttest is part of the statistics parametric, hence in accordance with the rules in statistics, data research must be parametric normally distributed or not. Was used in the testing program SPSS.

The decision by the experiment paired sample ttest:

1. If the probability it is significant $<0,05$ there is the difference significant

2. If the probability \& significant $<0,05$ so there is no significant difference

Non-parametric tested methods used in research is Wilcoxon test match pairs tests. This technique was a refinement of the mark if the test the figures the difference between positive and negative not taken into account while in the test Wilcoxon pairs test match up. This technique used to test hypotheses comparative two samples if the data is shaped ordinal [14].

Table 1. Visa NPM comparative test hypothesis

\begin{tabular}{|l|l|}
\hline \multicolumn{2}{|c|}{ Test Statistics } \\
\hline & Before \\
\hline & After \\
\hline $\mathrm{Z}$ & -1.069 \\
\hline Asymp. Sig. (2-tailed) & 0.285 \\
\hline
\end{tabular}

Based on the calculation on comparative test hypothesis by using Wilcoxon match pairs test above, known asymp.sig value .( 2-tailed) is 0.285 worth. Because of the value of 0.285 greater than 0.05 percentage point so it can be concluded that there is no significant difference on the perceived value of net profit margin before or after implementation of the visa company in Indonesia.

Table 2. Mastercard NPM comparative test hypothesis

\begin{tabular}{|l|l|}
\hline \multicolumn{2}{|c|}{ Test Statistics } \\
\hline & Before \\
\hline & After \\
\hline $\mathrm{Z}$ & -1.069 \\
\hline Asymp. Sig. (2-tailed) & 0.109 \\
\hline
\end{tabular}

Based on the results of the equation using Wilcoxon pairs test matchup showed the value of asymp.sig (2-tailed) of 0.109 where figure is greater than 0.05 . From the result has been concluded that there is no significant difference before and after the implementation of GPN as providers debit card in Indonesia seen from the net profit margin Mastercard company.

Table 3. Visa ROI comparative test hypothesis

\begin{tabular}{|l|l|}
\hline \multicolumn{2}{|c|}{ Test Statistics } \\
\hline & Before \\
\hline & After \\
\hline $\mathrm{Z}$ & -1.064 \\
\hline Asymp. Sig. (2-tailed) & 0.109 \\
\hline
\end{tabular}

After test hypothesis comparative parametric use Wilcoxon match pairs and test the significance before and after implementation of the GPN is 0.109 where 0.109 greater than 0.05 percentage point. It shows there is no significant differences before and after implementation of the GPN as service providers discharge card in Indonesia from the point of view of the value of the ratio of visa company return on investment.

Table 4. Mastercard ROI comparative test hypothesis

\begin{tabular}{|l|l|}
\hline \multicolumn{2}{|c|}{ Test Statistics } \\
\hline & Before \\
\hline & After \\
\hline $\mathrm{Z}$ & 0.000 \\
\hline Asymp. Sig. (2-tailed) & 1.000 \\
\hline
\end{tabular}

The result of the testing of hypotheses comparative conducted showed the value of significance of return on investment for which the figures building 1,000 , it is bigger than 0.05 percentage point. Based on the conclusions may be drawn that there is no significant difference before and after implementation of the discharge GPN as service providers in the new company Mastercard card in Indonesia in the value of the ratio of return on Investment.

Table 5. Visa ROE comparative test hypothesis

\begin{tabular}{|l|l|}
\hline \multicolumn{2}{|c|}{ Test Statistics } \\
\hline & Before \\
\hline & After \\
\hline $\mathrm{Z}$ & -1.064 \\
\hline Asymp. Sig. (2-tailed) & 0.109 \\
\hline
\end{tabular}

The indicated in the table in the figures from the comparative the testing of hypotheses using Wilcoxon pairs test match to compare the return on 
equity firm visa before and after the implementation of GPN. The calculation showing 0.109 where the figure is greater than 0.05 which means the absence of a significant difference in the return on equity both before and after the implementation of GPN.

Table 6. Mastercard ROE comparative test hypothesis

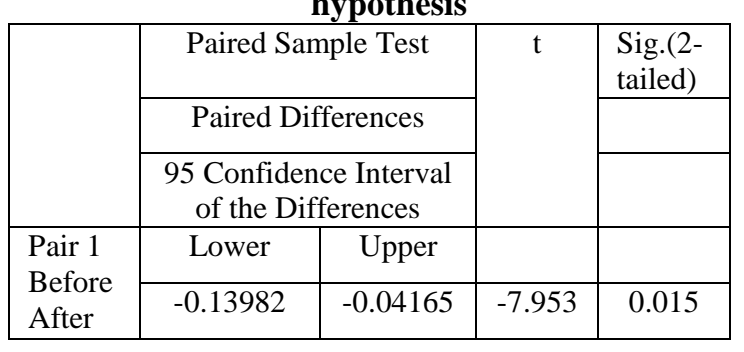

Table 6 described the results of the comparative hypothesis on ratios return on equity using the sample t-test paired. Its proceeds raise the significance of that data is 0.015 where the figure is smaller than 0.05 . The result has been concluded that there are significant differences on the ratio return on equity firm Mastercard after the implementation of GPN as providers debit card in Indonesia.

Based on the results of data processing and analysis that has been done in the previous sub-chapter regarding company performance using theprofitability ratio Net Profit Margin (NPM), Return On Investment (ROI) and Return On Equity (ROE) which has been carried out descriptively, normality and hypothesis testing to answer the problems in the previous chapter where this study aims to determine how much the profitability level of the Visa and Mastercard companies before and after the implementation of GPN as a debit service provider card in Indonesia. The following is a discussion of the results of data testing that has been done.

To answer the first hypothesis (H1) about the difference in the value of the Net Profit Margin (NPM) ratio for companies before and after GPN implementation, the comparative hypothesis testing performed is parametric analysis using the Wilcoxon Match Pairs Test because the nonnormality test uses the Kolmogrov-Smirnov Test number from the calculation is smaller than 0.05 which describes the data as being abnormally distributed. The results of the comparative test show the number 0.109 , the significance value is higher than 0.05 which indicates that there is no significant difference in the Net Profit Margin (NPM) profitability ratio on Visa. Even so, from the tests carried out descriptively there are numbers that show the increase in the level of Net Proft Margin (NPM) value of $15.5 \%$ in the quarter after the implementation of the GPN. The results of the testing (H1) of Visa companies show no significant difference before and after the implementation of GPN as a debit card service provider in Indonesia. Regarding theory, these results address an increase in management performance in generating profits for the company.

Hypothesis testing (H1) on Mastercard companies related to the comparison of the Net Profit Margin (NPM) value also uses the non-parametric Wilcoxon Match Pairs Test with the results of the Asymp calculation. Sig. (2-tailed) as much as 0.109 which means there is no significant difference seen from the value of the company's Net Porift Margin (NPM). However, the results of a descriptive test addressing a figure of $4.24 \%$, this figure shows an increase in the value of the company's Net Profit Margin (NPM) even though the increase is lower compared to Visa, which is also one of the debit card service companies. The conclusion of the testing that has been done is that there is no significant difference in the value of the Netcard Net Profit Margin (NPM) before and after the implementation of GPN in Indonesia. In terms of theory, Mastercard shows an increase in management performance in generating profits for the company.

Next is the hypothesis $(\mathrm{H} 2)$ which is related to the comparison of the level of profitability of the company seen from the value of Return On Investment (ROI). In company Visa normality test is done by using the Kolmogorov-Smirnov Test with the calculated address number 0001 which means that the processed data is not normally distributed so as to test the hypothesis of comparative been made by using the test non paramteris Wilcoxon Match Pairs Test then found the numbers of significance before and after implementation The GPN is 0.109 where 0.109 is greater than 0.05 , which means there are no significant differences before and after GPN implementation. The descriptive test addresses that the company experienced an increase in the value of Return on Investment (ROI) of $1.26 \%$. Based on the discussion, it can be concluded that there were no significant differences before and after the implementation of GPN as a debit service provider card in Indonesia as seen from the value of theratio Return On Investment Visa Company. If it is associated with the theory, the contribution of total assets to net income in the quarter before and after the implementation of the GPN is not much different or tends to be the same, the differences that occur before and after the implementation of the GPN are not significant.

Mastercard hypothesis $(\mathrm{H} 2)$ is related to the comparison of the level of profitability of the company from the value of Return On Equity (ROE) tested by using descriptive statistical tests, 
normality tests using the Kolmogrov-Smirnov Test and comparative hypothesis testing using the Wilcoxon Match Pairs est. The Wilcoxon Match Pairs are used because when testing the normality of the results of Asymp. Sig. (2-tailed) of 0.012 smaller than 0.05 then the data is declared to be abnormally distributed. The results of the comparative hypothesis testing show the number 1,000 where the number is greater than 0.05 , which means there is no significant difference. For descriptive testing, the results of the calculation show an increase of $1.01 \%$ on the value of the company's Return On Investment. If associated with the theory, the contribution of total assets to net income in the quarter before and after the implementation of the GPN tends to be the same. Thus it can be concluded that there is no significant difference in the value of the Return On Investment (ROI) of the Mastercard company before and after the implementation of GPN as a debit card service provider in Indonesia.

In thehypothesis third(H3) for Visa, the results of the descriptive test show an increase in the value of Return On Equity (ROE) of 0.0261 or $2.61 \%$. then in testing the normality, the results of the test address data are abnormally distributed so that to test the comparative hypothesis using the nonparametricdata analysis Wilcoxon Match Pairs Test. From the results of the comparative test calculation, the number is 0.109 where the rate is greater than 0.05 , which means that there is no significant difference in the value of the Return on Equity (ROE) of the company. If it is associated with the theory, the return on equity in the quarter after implementation is better than the return on equity in the quarter before the implementation of the GPN even though the value is not much different from the difference of $2.61 \%$. From the results of the tests above, it can be concluded that there is no significant difference in the value of Return on Equity (ROE) of Visa companies before and after the implementation of GPN as a debit card service provider in Indonesia.

Then for the third hypothesis (H3) in the company Mastercard the value of the results of the normality test conducted with the Kolmogrov-Smirnov Test shows a number of 0.20 . This number is greater than 0.05 which means the data is normally distributed, then the comparative hypothesis testing uses the parametricstatistic Sample T-test. The results of the Sig. (2-tailed) calculation on comparative testing show a number of 0.015 where the number is more than 0.05 , which means there are significant differences before and after the implementation of the GPN. This is supported by the value of the descriptive test results where there is a value of 0.0907 or $9.07 \%$. With regard to theory, Mastercard addresses an increase in management performance in generating profits for the company. From the above discussion it can be concluded that there are significant differences before and after the implementation of GPN as a debitservice provider card in Indonesia as seen from the value of the Return on Equity (ROE) of the Mastercard company.

The test results on all hypotheses that have been tested show that there are no significant differences in the ratio of NPM and ROI. The only significant difference is the Return On Equity (ROE) Mastercard value. But overall, the three hypotheses address the increase after the implementation of the GPN in Indonesia.

Table. 7 Company Financial Statements Before and After Implementation of GPN

\begin{tabular}{|c|c|c|c|c|c|}
\hline Object & Peiode & Description & NPM & ROI & ROE \\
\hline \multirow{6}{*}{ Visa } & Quarter 12017 & \multirow{3}{*}{ Before } & $46.4 \%$ & $3.26 \%$ & $6.52 \%$ \\
\hline & Quarter 22017 & & $9.61 \%$ & $0.68 \%$ & $1.39 \%$ \\
\hline & Quarter 32017 & & $45.1 \%$ & $3.21 \%$ & $6.44 \%$ \\
\hline & Quarter 12018 & \multirow{3}{*}{ After } & $51.8 \%$ & $3.75 \%$ & $7.55 \%$ \\
\hline & Quarter 22018 & & $51.3 \%$ & $3.77 \%$ & $7.63 \%$ \\
\hline & Quarter 32018 & & $44.4 \%$ & $3.41 \%$ & $6.99 \%$ \\
\hline \multicolumn{3}{|c|}{ Difference } & $15.5 \%$ & $1.26 \%$ & $2.61 \%$ \\
\hline \multirow{6}{*}{ Mastercard } & Quarter 12017 & \multirow{3}{*}{ Before } & $39.5 \%$ & $5.82 \%$ & $19.1 \%$ \\
\hline & Quarter 22017 & & $38.5 \%$ & $5.93 \%$ & $20.0 \%$ \\
\hline & Quarter 32017 & & $42.0 \%$ & $6.83 \%$ & $22.1 \%$ \\
\hline & Quarter 12018 & \multirow{3}{*}{ After } & $41.6 \%$ & $6.50 \%$ & $26.0 \%$ \\
\hline & Quarter 22018 & & $42.8 \%$ & $6.98 \%$ & $29.7 \%$ \\
\hline & Quarter 32018 & & $48.7 \%$ & $8.13 \%$ & $32.7 \%$ \\
\hline \multicolumn{3}{|c|}{ Difference } & $4.24 \%$ & $1.01 \%$ & $9.07 \%$ \\
\hline
\end{tabular}




\section{CONCLUSIONS}

This study aims to compare the benefits of Visa and Mastercard companies using profitability ratios including Net Profit Margin (NPM), Return On Investment (ROI) and Return On Equity (ROI) for the period of 2016 to 2018. Based on the results of descriptive testing, normality and comparative hypothesis testing, the conclusion is obtained that the results of this study indicate that no there are significant differences the value of NPM, ROI and ROE Visa while the ROE value of Mastercrad has increased which shows an increase in management performance in generating profits for companies.

\section{REFERENCES}

[1] Cermati. (2016, Agustus 25). Pengetahuan Umum Seputar Kartu Debit. Retreived September 10, 2018, from Cermati.com: https://www.cermati.com

[2] Bank Indonesia, Edukasi dan Perlindungan Konsumen SP. (2017). Jakarta. Retrieved September 12, 2018, from Bank Indonesia: https://www.bi.go.id

[3] Supomo, A. I . (2002). Kartu Kredit, Kartu Debit dan E-Banking: Menuju Cashless Society. Jurnal Pangsa, 6 (VI), 177-182.
[4] Petriela, Y. (2015, Februari 2). Kartu Debit, Perbankan Siap Migrasi Teknologi Magnetik Striple ke Chip. Rereived September 12, 2018, from Finansial: https://finansial.bisnis.com

[5] Bank Indonesia, Alat Pembayaran Menggunakan Kartu (APMK). (2017). Jakarta. Retrieved September 12, 2018, from Bank Indonesia: https://www.bi.go.id

[6]. Setiawan, R. D. S. (2018, April 9) BI: Per Januari 2018, 167 Juta Kartu Debit Beredar di Indoneisa. Retrieved September 12, 2018 from Kompas.com: https://ekonomi.kompas.com

[7] Purnomo, H. (2018, Agustus 1) Tiga Kebijakan Buktikan Jokowi Bernyali 'Lawan' Asing. Retrieved September 12, 2018 from Cnbc: https://www.cnbcindonesia.com

[8] Fahmi, I. (2011). Analisis Laporan Keuangan. Bandung: Alfabeta.

[9] Harmono. (2009). Manajemen Keuangan Berbasis Balaced Scorecard. Jakarta: Sinar Grafika Offset.

[10] Wardiyah, M. L. (2017). Analisis Laporan keuangan. Bandung: cv Pustaka Setia.

[11]Fahmi, I. (2014) Pengantar Manajemen Keuangan: Afabeta.

[12] Astuti, D. (2004). Manajemen Keuangan Perusahaan. Jakarta: Ghalia Indonesia.

[13] Sugiyono. (2015) Statistika Untuk Penelitian. Bandung: Alfabeta

[14] Sugiyono. (2010) Statistika Untuk Penelitian. Bandung: Alfabeta 